\title{
PENGARUH FREKUENSI IKLAN TELEVISI DAN KEUNGGULAN BERSAING TERHADAP MINAT BELI AIR MINUM ISI ULANG AQUA \\ DI KECAMATAN MEUREUDU \\ KABUPATEN PIDIE JAYA
}

\author{
Ismayli, (1) , Cut Italiana,(2) \\ 1,2Program Studi D.III Keuangan dan Perbankan Fakultas Ekonomi \\ Universitas Jabal Ghafur Sigli
}

\begin{abstract}
ABSTRAK
Penelitian ini bertujuan untuk mengetahui Pengaruh Frekuensi Iklan Televisi dan Keunggulan Bersaing terhadap Minat Beli Air Minum Isi Ulang Aqua di Kecamatan Meureudu Kabupaten Pidie Jaya. Sampel dalam penelitian ini 100 orang konsumen di Kecamatan Meureudu Kabupaten Pidie Jaya, data dikumpulkan melalui pengajuan kuesioner, analisis data menggunakan regresi linier berganda. Hasil penelitian nilai koefisien korelasi diperoleh sebesar 0,769 atau 76,9\% yang bermakna bahwa, ada hubungan antara variabel independen dengan variabel dependen. Variabel frekuensi iklan televisi (X1) dan Keunggulan bersaing (X2) mempunyai hubungan dengan variabel minat beli. Semakin tinggi nilai koefisien yang diperoleh maka semakin tinggi hubungan antar variabel tersebut.

Nilai koefisien diterminai (R2) bertujuan untuk mengetahui pengaruh antara variabel bebas dengan variabel terikat. Nilai koefisien diterminasi diperoleh sebesar 71,6\% antara frekuensi iklan televisi (X1) dan keunggulan bersaing (X2) mempunyai pengaruh nyata terhadap minat beli. Dengan kata lain variabel frekuensi iklan televisi dan keunggulan bersaing berpengaruh secara signifikan sebesar $71,6 \%$ terhadap tingkat minat beli beli produk air minum isi ulang Aqua di Kecamatan Meureudu Kabupaten Pidie Jaya sedangkan selebihnya sebesar 28,4\% dipengaruhi oleh variabel lain diluar persamaan ini.

Uji hipotesis terbukti bahwa T-hitung > T-tabel. Ini berarti naik turunnya minat beli dipengaruhi secara nyata oleh variabel frekuensi iklan televisi dan keunggulan besaing. Uji-F (uji simultan) adalah menguji kebersamaan variabel bebas dengan variabel terikat secara keseluruhan. Hasil pengujian secara simultan diperoleh Fhitung $=138.049$, sedangkan Ftabel $=$ 3,14 pada tingkat signifikan 5\%, hal ini memperlihatkan bahwa Fhitung > Ftabel dengan demikian keputusan yang diambil dalam penelitian ini adalah ada pengaruh yang signifikan secara bersamaan antara variabel X1 dan X2 dengan Y. Sehingga dalam penelitian ini diambil keputusan bahwa menerima hipotesis Ha dan menolak hipotesis Ho. Hipotesis yang telah ditetapkan dapat di terima yaitu frekuensi iklan televisi dan keunggulan bersaing secara siginifikan berpengaruh terhadap minat beli air minum isi ulang Aqua.
\end{abstract}

Kata Kunci: Frekuensi Iklan Televisi, Keunggulan Bersaing dan Minat Beli.

\section{THE EFFECT OF TELEVISION ADVERTISING AND COMPETITIVE ADVANTAGES TOWARDS INTEREST IN BUYING AQUA REFILL DRINKING WATER IN THE MEUREUDU DISTRICT PIDIE JAYA DISTRICT}

Ismayli, (1) Cut Italiana, (2)

Permanent Lecturer D.III Finance and Banking Faculty of Economics Jabal Ghafur Sigli University

\begin{abstract}
This study aims to determine the Effect of Television Advertising Frequency and Competitive Advantage on Interest in Purchasing Aqua Refill Drinking Water in Meureudu District, Pidie Jaya Regency. The sample in this study was 100 consumers in Meureudu Subdistrict, Pidie Jaya
\end{abstract}


District, data were collected through a questionnaire, data analysis used multiple linear regression. The results of the correlation coefficient values obtained by 0.769 or $76.9 \%$ which means that, there is a relationship between the independent variable with the dependent variable. The variable frequency of television advertising (X1) and competitive advantage (X2) have a relationship with the variable purchase interest. The higher the coefficient value obtained, the higher the relationship between these variables.

The coefficient value measured (R2) aims to determine the effect of the independent variable with the dependent variable. The term coefficient value obtained by $71.6 \%$ between the frequency of television advertising (X1) and competitive advantage (X2) has a real influence on buying interest. In other words, the variable frequency of television advertisements and competitive advantage significantly influence $71.6 \%$ of the level of purchase and purchase of Aqua refill drinking water products in Meureudu District, Pidie Jaya Regency while the rest of $28.4 \%$ is influenced by other variables outside this equation.

Hypothesis testing proved that T-count> T-table. This means the ups and downs of buying interest are significantly influenced by the variable frequency of television advertisements and competitive advantages. F-test (simultaneous test) is to test the togetherness of the independent variable with the dependent variable as a whole. Simultaneous test results obtained Fcount $=$ 138.049, while Ftable $=3.14$ at a significant level of 5\%, this shows that Fcount $>$ Ftable thus the decision taken in this study is that there is a significant influence simultaneously between variables $\mathrm{X} 1$ and $\mathrm{X} 2$ with $\mathrm{Y}$ So that in this study the decision was taken to accept the Ha hypothesis and reject the Ho hypothesis. The hypothesis that has been set can be accepted, namely the frequency of television advertisements and competitive advantage significantly affect the interest in buying drinking water refill Aqua.

Keywords: Frequency of Television Ads, Competitive Advantages and Purchase Interest

\section{Pendahuluan}

\section{Latar Belakang Masalah}

Kelangsungan hidup suatu perusahaan perlu diperhatikan beberapa faktor keunggulan, seperti strategi pemasaran, peluang pemasaran, finansial, teknologi yang harus diperhatikan untuk pengembangan suatu perusahaan. Perhatian perusahaan terhadap peluang pasar merupakan faktor penting untuk diperhatikan, karena menentukan terhadap perluasan pasar dalam meningkatkan penjualan.

Dewasa ini dalam menangani keluhan konsumen sebagai pemakai produk, perlu mengumpulkan informasi yang akurat sesuai dengan permasalahan yang ada. Program pemasaran harus bertindak aktif dalam menangani keluhan tersebut, sehingga upaya peningkatan kegiatan pemasaran dapat dilakukan sesuai dengan yang diharapkan, oleh karena itu kegiatan pemasaran membutuhkan suatu riset pemasaran sebagai alat untuk mendapatkan informasi tentang kegiatan pemasaran.

Televisi merupakan salah satu media elektronik yang dapat menjangkau seluruh lapisan masyarakat dari perkotaan sampai pedesaan. Keberadaan televisi sudah menjadi sangat populer dimasyarakat, dan sudah tidak dapat lagi dipisahkan dari teknologi dan informasi. Televisi memudahkan masyarakat dalam mengetahui peristiwa yang terjadi dari berbagai belahan dunia dengan cepat dan serentak.

Iklan televisi telah mengangkat medium iklan kedalam konteks yang sangat kompleks namun jelas, berimajinasi namun kontekstual, penuh fantasi namun nyata. Kekaguman-kekaguman itu tidak lepas dari peran televisi yang telah menghidupkan iklan dalam dunia kognisi pemirsa serta penuh dengan angan-angan. Padahal televisi hanya mengandalkan kemampuan audiovisual dan prinsip-prinsip komunikasi massa sebagai media konstruksi. Maka, sesungguhnya copywriter dan visualize lah yang paling besar perannya dalam memberi nuansa hidup kepada iklan televisi.

Tayangan iklan Televisi yang tepat, baik jadwal maupun frekuensi tayangan menjadi sasaran yang baik bagi pemirasa menonton iklan tersebut, sehingga dapat 
menarik minat konsumen untuk membeli produk.

Semakin menarik suatu iklan dan semakin sering dilihat, dibaca dan didengar maka semakin akrab konsumen dengan produk-produk yang diiklankan. Kedekatan konsumen denganproduk mendorong konsumen untuk mengkonsumsinya. Adanya suatu dorongan kebutuhan yang ada pada diri seseorang merupakan awal timbulnya keputusan pembelian suatu produk.

Dalam memperkenalkan produk atau mempromosikan produk barunya maka pemasar dapat secara serentak dapat menjagkau wilayah yang luas bahkan keseluruh wilayah yang memiliki jangkauan siaran televisi.

Keunggulan bersaing (Competitive Advantage) adalah jantung kinerjaperusahaan dalam pasar bersaing. Keunggulan bersaing pada dasarnya tumbuh dari nilai atau manfaat yang diciptakan oleh perusahaan bagi para pembelinya yang lebih dari biaya yang harus dikeluarkan untuk menciptakannya. Nilai atau manfaat inilah yang sedia dibayar oleh pembeli, dan nilai yang unggul berasal dari penawaran harga yang lebih rendah ketimbang harga pesaing untuk manfaat setara ataupenawaran manfaat unik yang melebihi harga yang ditawarkan.

Keunggulan bersaing dapat diperoleh sebagian besar dari sumber daya dan modal. Sumber daya yang dimaksud adalah kekuatan dan kelemahan kinerja pemasaran, sedangkan modal diartikan sebagai kemampuan perusahaan didalam mengelola sumberdaya yang dimiliki untuk bekerja sama seperti tim kerja dalam satu departemen, atau dengan kata lain tinggi rendahnya kinerja pemasaran akan berpengaruh kepada tinggi rendahnya keunggulan bersaing perusahaan.

Minat adalah sesuatu yang pribadi dan berhubungan dengan sikap, individu yang berminat terhadap suatu obyek akan mempunyai kekuatan atau dorongan untuk melakukan serangkaian tingkah laku untuk mendekati atau mendapatkan objek tersebut. Minat beli timbul setelah adanya proses evaluasi alternatif dan di dalam proses evaluasi, seseorang akan membuat suatu rangkaian pilihan mengenai produk yang hendak dibeli atas dasar merek maupun minat.

Produk air minum isi ulang Aqua telah dilakukan promosi melalui iklan televis, namun frekuensi tayangan belum tepat sesuai dengan waktu dan harapan konsumen. Begitu juga dengan semakin banyaknya keluar produk produk air minum isi ulang merek lain merupakan saingan bagi produk air minum isi ulang Aqua.

Berdasarkan masalah di atas penulis tertarik meneliti tentang, Pengaruh Frekuensi Iklan Televisi dan Keunggulan Bersaing terhadap Minat Beli Air Minum Isi Ulang Aqua di Kecamatan Meureudu Kabupaten Pidie Jaya.

\section{Rumusan Masalah}

1. Apakah variabel Frekuensi Iklan Televisi berpengaruh terhadap Minat Beli Air Minum Isi Ulang Aqua di Kecamatan Meureudu Kabupaten Pidie Jaya.

2. Apakah variabel Keunggulan bersaing berpengaruh terhadap Minat Beli Air Minum Isi Ulang Aqua di Kecamatan Meureudu Kabupaten Pidie Jaya.

3. Variabel manakah secara simultan berpengaruh terhadap Minat Beli Air Minum Isi Ulang Aqua di Kecamatan Meureudu Kabupaten Pidie Jaya.

\section{Tujuan Penelitian}

1. Untuk mengetahui pengaruh Frekuensi Iklan Televisi terhadap Minat Beli Air Minum Isi Ulang Aqua di Kecamatan Meureudu Kabupaten Pidie Jaya.

2. Untuk mengetahui pengaruh Keunggulan bersaing terhadap Minat Beli Air Minum Isi Ulang Aqua di Kecamatan Meureudu Kabupaten Pidie Jaya.

3. Untuk mengetahui variabel manakah secara simultan berpengaruh terhadap Minat Beli Air Minum Isi Ulang Aqua di Kecamatan Meureudu Kabupaten Pidie Jaya.

\section{Studi Kepustakaan}

Iklan televisi sebagai salah satu iklan 
elektronik ditampilkan melalui kombinasi media audio dan media visual. Pada saat ini, banyak perusahaan televisi swasta yang menyajikan berbagai tanyangan baik itu tanyangan yang mengandung hiburan atau pendidikan (Kotler, 2012).

Kelebihan dan kelemahan iklan televise Menurut Kasali (2010) kelebihan dan kelemahan iklan televisi adalah sebagai berikut:

Kelebihan iklan televisi:1) Efesiensi biaya, salah satu keunggulan televisi adalah kemampuan menjangkau khalayak sasaran yang sangat luas. Televisi menjangkau khalayak sasaran yang dapat dicapai media lainnya, tapi juga khalayak yang tidak dijangkau oleh media cetak. 2) Dampak yang kuat, kemampuannya menimbulkan dampak yang kuat terhadap kosumen, dengan tekanan pada sekaligus dua indra yaitu penglihatan dan pendengaran. 3) Pengaruh yang kuat, televisi mempunyai kemampuan yang kuat untuk mempengaruhi persepsi kalayak sasaran, kebanyakan masyarakat meluangkan waktunya dimuka televisi, sebagai sumber berita, hiburan dan sarana pendidikan. Kebayakan calon pembeli percaya pada perusahaan yang mengiklankan produknya ditelevisi daripada tidak sama sekali.

Ideal bagi pelanggan eceran, iklan televisi dapat mengjangkau kalangan pedagang eceran sebaik ia mengjangkau konsumen. Selain karena para pedagang eceran juga suka menonton televisi seperti juga orang lain, hal ini disebabkan iklaniklan televisi memang sangat membantu usaha mereka. 5) Terkait erat dengan media lain, jika konsumen memerlukan informasi lebih lanjut, maka iklan televisi bisa dipadukan dengan iklan dimajalah-majalah, khususnya majalah yang mengulas acara televisi. Perusahaan televisi juga sering kali menawarkan jasa layanan telepon, atau fasilitas komputerisasi pemasanan, dan nomor telepon atau keterangan penggunaan fasilitas tersebut dapat disebutkan dalam iklan dimedia cetak atau dalam tayangan iklan televisi itu sendiri.

Kelemahan iklan televisi:1)Biaya yang besar, beriklan ditelevisi mengeluarkan biaya yang cukup mahal dan sangat ekstren untuk mempromosikan dan menyiarkan siaran komersial. Biaya produksi, termasuk biaya pembuatan iklan dan honorarium artis yang terlibat bisa menghabiskan puluhan jutaan rupiah, belum lagi penyiarannya yang harus diulang-ulang pada jam-jam siaran utama.2)Khalayak yang tidak selektif, sekalipun berbagai teknologi telah diperkenalkan untuk mengjangkau sasaran yang lebih efektif, televisi tetap sebuah media yang tidak selektif, segmentasinya tidak setajam surat kabr atau majalah.jadi iklan yang disiarkan ditelevisi memiliki kemungkinan mengjangkau pasar yang tidak tepat.3)Kesulitan teknis, media ini tidakluwes dalam pengaturan teknis, iklaniklan yang telah dibuat tidak dapat diubah begitu saja jadwalnya, apalagi menjelang jam-jam penyiaran.

Keunggulan Bersaing/kompetitif (competitive advantage) adalah kemampuan yang diperoleh melalui karakteristik dan sumber daya suatu perusahaan untuk memiliki kinerja yang lebih tinggi dibandingkan perusahaan lain pada industri atau pasar yang sama. Jika dilihat dari sumberdaya manusia maka. Keunggulan Bersaing/kompetitif (competitive advantage) adalah kemampuan yang diperoleh melalui karakteristik dan sumber daya seseorang untuk memiliki kinerja yang lebih tinggi dibandingkan dengan orang lain pada setiap keahlian dan kecerdasan dalam mengatasi setiap masalah.

Pengertian keunggulan bersaing menurut Dirgantoro (2011) adalah perkembangan dari nilai yang mampu diciptakan perusahaan untuk pembelinya". Menurut Agustinus (2010) memberikan pengertian keunggulan bersaing, adalah: "Sesuatu yang memungkinkan sebuah perusahaan memperoleh keuntungan yang lebih tinggi dibandingkan dengan rata-rata keuntungan yang diperoleh pesaing dalam industri. Semakin kuat keunggulan yang dimiliki akan semakin tinggi keuntungan yang diperoleh perusahaan dan begitu pula sebaliknya". 
Thamrin (2011) minat beli adalah merupakan bagian dari komponen perilaku konsumen dalam sikap mengkonsumsi, kecenderungan responden untuk bertindak sebelum keputusan membeli benar-benar dilaksanakan. Menurut Liana (2009) adalah minat beli merupakan sesuatu yang berhubungan dengan rencana konsumen untuk membeli produk tertentu serta berapa banyak unit produk yang dibutuhkan pada periode tertentu.

Schiffman (2011) menjelaskan bahwa pengaruh eksternal, kesadaran akan kebutuhan, pengenalan produk dan evaluasi alternatif adalah hal yang dapat menimbulkan minat beli konsumen. Pengaruh eksternal ini terdiri dari usaha pemasaran dan faktor sosial budaya.

\section{Kerangka Pemikiran}

Minat beli dipengaruhi oleh beberapa faktor, dalam penelitian ini dipilih variabel frekuensi iklan telivisi dan keunggulan bersaing sebagai variabel indenpenden, sedangkan minat beli adalah variabel dependen, sebagaimana terlihat pada Gambar berikut ini.

Gambar: Kerangka Pemikiran

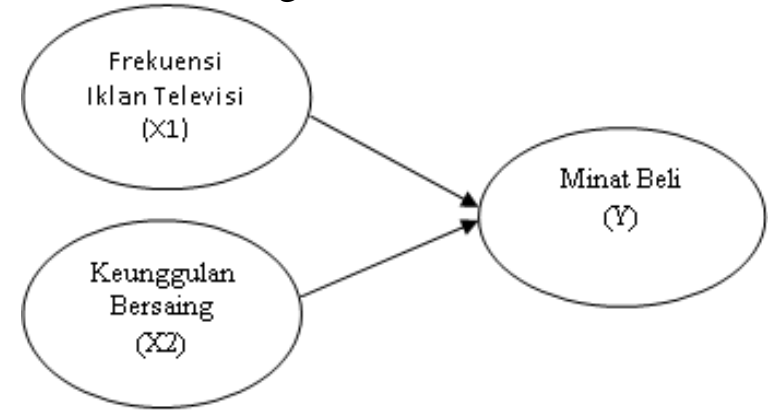

\section{Hipotesis}

Hipotesis yang ditetapkan dalam penelitian ini ada pengaruh yang signifikan antara variabel frekuensi iklan televisi dan Keunggulan Bersaing terhadap Minat Beli Air Minum Isi Ulang Aqua di Kecamatan Meureudu Kabupaten Pidie Jaya.

\section{Metode Penelitian}

Penelitian ini dilakukan di Depot Air Minum Isi Ulang Aqua di Kecamatan Meureudu Kabupaten Pidie Jaya, waktu penelitian mulai tanggal 23 Februari sampai dengan 5 Maret 2020.

\section{Populasi dan Sampel}

Mengingat populasi dalam penelitian ini tidak diketahui jumlahnya, maka untuk menentukan jumlah sampel digunakan rumus unknown population, (Sudjana, 2011:152) sebagai berikut:

$n=(0,25) \frac{(z \alpha / 2)^{2}}{e}$

Di mana:

$\begin{aligned} \mathrm{n} & =\text { Jumlah sampel } \\ \mathrm{z} \alpha / 2= & \text { Nilai yang didapatkan dari tabel } \\ & \text { normal atas tingkat keyakinan } \\ \mathrm{e} & =\text { Kesalahan dalam penarikansampel }\end{aligned}$

Dalam penelitian ini tingkat keyakinan ditentukan $90 \%$, maka nilai za/2 adalah 1,96 dan tingkat kesalahan penarikan sebesar $10 \%$, sehingga diperoleh besaran sampel sebagai berikut:

$\mathrm{n}=(0,25) \frac{(1,96 / 2)^{2}}{0,1}$

$\mathrm{n}=96,4$

$\mathrm{n}=96$ responden

Dengan demikian sampel yang diteliti dalam penelitian dibulatkan menjadi 100 orang responden.

\section{Teknik Pengumpulan Data}

Untuk mendapatkan data sebagaimana yang diperlukan, maka dilakukan serangkaian penelitian dengan cara:

\section{Observasi}

Penulis akan mezakukan tinjauan langsung ke lapangan atau melakukan pengamatan langsung pada objek penelitian yaitu pada sejumlah depok air minum isi ulang Aqua di Kecamatan Meureudu Kabupaten Pidie Jaya.

\section{Kuesioner}

Menyusun sejumlah daftar pertanyaan kemudian diajukan kepada responden yaitu masyarakat yang berminat dengan produk air minum isi ulang Aqua.

\section{Teknik Analisis Data}

Analisis data bersifat kuantitatif yaitu untuk mengetahui pengaruh variabel independen dengan variabel dependen dengan menggunakan rumus regresi linier berganda sebagai berikut: 
Jurnal Sains Riset (JSR)

$p$-ISSN 2088-0952, $e$-ISSN 2714-531X

$\mathrm{Y}=\mathrm{a}+\mathrm{b} 1 \mathrm{x} 1+\mathrm{b} 2 \mathrm{x} 2+\mathrm{e}$ (Sudjana.

2011:192)

Keterangan

$\mathrm{Y}=$ Minat Beli

$\mathrm{X} 1=$ Frekuensi Iklan Televisi

$\mathrm{X} 2=$ Keunggulan Bersaing

$\mathrm{a}=$ Konstanta

$\mathrm{b}=$ Koefisien regresi

$\mathrm{e}=$ Error term

\section{Hasil Penelitian Dan Pembahasan Karakteristik Responden}

Tabel 4.1

Karakteristik Responden

\begin{tabular}{|c|l|c|c|}
\hline No & \multicolumn{1}{|c|}{ Jenis Kelamin } & $\begin{array}{c}\text { Frekuensi } \\
\text { (orang) }\end{array}$ & $\begin{array}{c}\text { Persentase } \\
(\%)\end{array}$ \\
\hline 1. & Laki laki & 46 & 46,0 \\
2. & Perempuan & 54 & 54,0 \\
\hline & \multicolumn{1}{|c|}{ Umur } & & \\
\hline 1 & $17-29$ tahun & 17 & 17,0 \\
2. & $30-39$ tahun & 29 & 29,0 \\
3. & $40-49$ tahun & 41 & 41.0 \\
4. & 50 tahun & 13 & 13,0 \\
\hline & \multicolumn{1}{|c|}{ Tingkat } & & \\
& \multicolumn{1}{|c|}{ Pendidikan } & & \\
\hline 1 & SD/sederajat & 21 & 21,0 \\
2 & SMP/sederajat & 18 & 18,0 \\
3 & SMA/sederajat & 33 & 33,0 \\
4 & Sarjana & 28 & 28,0 \\
\hline & \multicolumn{1}{|c|}{ Status } & & \\
\hline 1. & Kawin & 65 & 65,0 \\
2. & Belumkawin & 35 & 350 \\
\hline & \multicolumn{1}{|c|}{ Pekerjaan } & & \\
\hline 1. & Petani & 25 & 25,0 \\
2. & Wiraswasta & 22 & 22,0 \\
3. & Pelajar/Mahasiswa & 15 & 15,0 \\
4. & PNS & 34 & 34,0 \\
5. & Lain lain & 8 & 8,0 \\
& & & \\
\hline
\end{tabular}

Sumber: Data Primer diolah (2020)

\section{Uji Normalitas}

Uji normalitas digunakan untuk menguji data dari sampel yang diambil normal ataupun tidak. Sampel yang di fokuskan dalam penelitian ini terlihat semuanya aktif dan berfungsi dalam memberikan pernyataan melalui kuesioner yang diberikan. Residual variabel yang

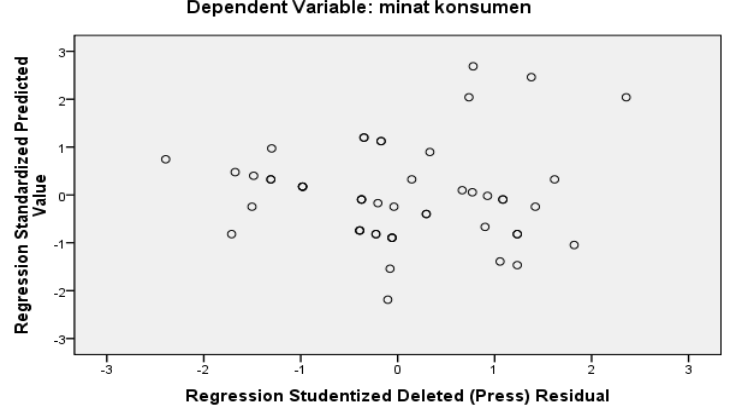




\section{Analisis Regresi Linier Berganda}

Berdasarkan uji statistik dapat dilihat persamaan regresi linier berganda. Nilai koefisien korelasi diperoleh sebesar 0,769 atau $76,9 \%$ yang bermakna bahwa, ada hubungan antara variabel independen dengan variabel dependen.

Dengan kata lain, variabel frekuensi iklan televisi (X1) dan Keunggulan bersaing (X2) mempunyai hubungan dengan variabel minat beli. Semakin tinggi nilai koefisien yang diperoleh maka semakin tinggi hubungan antar variabel tersebut.

Selanjutnya koefisien diterminai $\left(\mathrm{R}^{2}\right)$ bertujuan untuk mengetahui pengaruh antara variabel bebas dengan variabel terikat. Nilai koefisien diterminasi diperoleh sebesar 0,716 atau sebesar $71,6 \%$ antara frekuensi iklan televisi (X1) dan keunggulan bersaing (X2) mempunyai pengaruh nyata terhadap minat beli. Dengan kata lain variabel frekuensi iklan televisi dan keunggulan bersaing berpengaruh secara signifikan sebesar $71,6 \%$ terhadap tingkat minat beli beli produk air minum isi ulang Aqua di Kecamatan Meureudu Kabupaten Pidie Jaya sedangkan selebihnya sebesar 28,4\% dipengaruhi oleh variabel lain diluar persamaan ini.

\section{Uji Hipotesis}

\section{Uji T}

Uji $t$ bertujuan untuk menguji hipotesis berdasarkan hasil uji $\mathrm{T}$ variabel $\mathrm{Y}$ (minat beli) diperoleh nilai $\mathrm{T}$-hitung sebesar 3,146 dan $\mathrm{T}$-tabel pada tingkat kepercayaan $0,05 \%$ sebesar 1,661. Untuk variabel X1 (frekuensi iklan televisi) diperoleh nilai nilai $\mathrm{T}_{\text {-hitung }}$ sebesar 2.767 dan $\mathrm{T}$-tabel pada tingkat kepercayaan $0,05 \%$ sebesar 1,661. Sedangkan variabel X2 (keunggulan bersaing) diperoleh nilai $\mathrm{T}$-hitung sebesar 1.817 dan $\mathrm{T}_{\text {-tabel }}$ pada tingkat kepercayaan $0,05 \%$ sebesar 1,661. Dengan demikian terbukti bahwa $\mathrm{T}_{\text {-hitung }}>\mathrm{T}$-tabel. Ini berarti naik turunnya minat beli dipengaruhi secara nyata oleh variabel frekuensi iklan televisi dan keunggulan besaing.

\section{Uji F}

Uji-F (uji simultan) adalah menguji kebersamaan variabel bebas dengan variabel terikat secara keseluruhan. Hasil pengujian secara simultan diperoleh $F_{\text {hitung }}=138.049$, sedangkan $\mathrm{F}_{\text {tabel }}=3,14$ pada tingkat signifikan 5\%, hal ini memperlihatkan bahwa $\mathrm{F}_{\text {hitung }}>\mathrm{F}_{\text {tabel }}$ dengan demikian keputusan yang diambil dalam penelitian ini adalah ada pengaruh yang signifikan secara bersamaan antara variabel $\mathrm{X} 1$ dan $\mathrm{X} 2$ dengan $Y$. Sehingga dalam penelitian ini diambil keputusan bahwa menerima hipotesis $\mathrm{Ha}$ dan menolak hipotesis Ho. Hipotesis yang telah ditetapkan dapat di terima yaitu frekuensi iklan televisi dan keunggulan bersaing secara siginifikan berpengaruh terhadap minat beli air minum isi ulang Aqua.

\section{Kesimpulan dan Saran}

a. Nilai koefisien korelasi diperoleh sebesar 0,769 atau $76,9 \%$ yang bermakna bahwa, ada hubungan antara variabel independen dengan variabel dependen. Variabel frekuensi iklan televisi (X1) dan Keunggulan bersaing (X2) mempunyai hubungan dengan variabel minat beli. Semakin tinggi nilai koefisien yang diperoleh maka semakin tinggi hubungan antar variabel tersebut.

b. Nilai koefisien diterminai $\left(\mathrm{R}^{2}\right)$ bertujuan untuk mengetahui pengaruh antara variabel bebas dengan variabel terikat. Nilai koefisien diterminasi diperoleh sebesar $71,6 \%$ antara frekuensi iklan televisi (X1) dan keunggulan bersaing (X2) mempunyai pengaruh nyata terhadap minat beli. Dengan kata lain variabel frekuensi iklan televisi dan keunggulan bersaing berpengaruh secara signifikan sebesar $71,6 \%$ terhadap tingkat minat beli beli produk air minum isi ulang Aqua di Kecamatan Meureudu Kabupaten Pidie Jaya sedangkan selebihnya sebesar $28,4 \%$ dipengaruhi oleh variabel lain diluar persamaan ini. 


\section{Saran}

a. Perlu penayangan iklan telivisi sesuai dengan waktu yang tepat, sehingga konsumen dapat mengetahui tentang keberadaan air minum isi ulang Aqua, sehingga semakin tinggi minat beli konsumen.

b. Air minum isi ulang Aqua terus meningkatkan kualitasnya agar bertahan dalam persaingan dengan minuman isi ulang merek yang lain.

\section{DAFTAR PUSTAKA}

Arikunto, Suhaisimi, 2011. Prosedur Penelitian dan Penulisan Karya Tulis Ilmiah, Jakarta, Rineka Cipta.

Buchari, A, 2011. Manajemen Pemasaran dan Pemasaran Jasa, Bandung, Alfabeta.

Kasali. 2010. Manajemen Pemasaran, Jakarta: Rineka Cipta.

Kasmir, 2010, Studi Kelayakan Bisnis, Jakarta, Rineka Cipta.
Kotler, Philip 2011. Analisis Pemasaran Suatu Pengendalian, Jakarta, Erlangga.

Liana, 2009. Manajemen Perusahaan, Jakarta: Gramedia Grafika.

Lupiyoadi, 2012, Sistem pemasaran Terpadu, Edisi II, Jakarta, Erlangga.

Thamrin, 2011. Dasar dasar Pemasaran. Jakarta: Pustaka Nasional

Tjiptono, 2009. Strategi Pemasaran Modern, Yogyakarta, Andi Offset.

Sudjana, 2011. Metode Statistik, Jakarta, Erlangga.

Supranto, 200611, Pengukuran tingkat Kepuasan Pelanggan, Jakarta, Rineka Cipta.

Schiffman, 2011. Manajemen Pemasaran Modern, Jakarta: Rineka Cipta. 